\title{
Policy Options to Mitigate the Impacts of Green Gentrification When Constructing New Bike Paths in the Madison Area
}

\section{$\underline{\text { Julie Davis }}^{1}, \underline{\text { Brittany Baur }}^{2,6}, \underline{\text { Sarah Alexander }}^{3}, \underline{\text { Ben }}$ Bachmann $^{4}$}

1University of Wisconsin-Madison, Department of Astronomy, Madison, WI

2University of Wisconsin-Madison, Wisconsin Institute for Discovery, Madison, WI

3University of Wisconsin-Madison, Department of Civil \& Environmental Engineering, Madison, WI

4University of Wisconsin-Madison, Department of Chemistry, Madison, WI

https://doi.org/10.38126/ISPG180409

Corresponding author: babaur@wisc.edu

Keywords: green gentrification; sustainable infrastructure; biking; climate change; equity; Wisconsin

Executive Summary: To address changing climate patterns, cities in the US are expanding sustainable transportation options and implementing green infrastructure. Sustainable infrastructure projects help communities adapt, decrease $\mathrm{CO}_{2}$ emissions, promote community health, and provide economic benefits. These projects can also have unintended consequences, increasing gentrification and displacement of vulnerable communities through increased property values (i.e., green gentrification). The City of Madison maintains an extensive system of bike trails and continues to expand community access, with three projects recently completed or in development. We recommend that the City of Madison alter policy to use taxincrement financing or community land trusts as a preventative measure to mitigate green gentrification of nearby areas for all current and future bike path construction projects.

\section{Background}

Developing urban bike paths and other sustainable infrastructure is important for combating climate change and promoting community health. However, benefits are not always equitably distributed. New sustainable infrastructure projects can have unintended consequences, increasing gentrification and displacement of surrounding vulnerable communities through increased property values. While additional property value can benefit communities through greater tax-revenue, it often increases rent for local tenants. Thus, benefits of infrastructure development are unequally distributed among community members, displacing people with fewer resources. To prevent this "green gentrification," where implementation of green space excludes or displaces disenfranchised residents, preemptive measures are necessary to ensure equity. Urban planning experts argue that cities should be proactive and preserve affordable housing before implementing green infrastructure (Black 2020). For example, an abandoned rail line in Chicago was recently renovated into 2.7 miles of multi-use trail, serving as a transportation corridor and green space ("The 606"). The collaborative project resulted in green gentrification through higher property values, new development, and displacement of longtime residents (Black 2020). In 2018, property taxes near The 606 area saw the largest increase of any part of Chicago-over ten times the City average (Black 2020). While the Chicago Mayor's office promised to balance increased property values with protecting longtime residents, advocacy groups argue that rent subsidies were subject to future availability, allowing landlords to pursue higher-value options (Byrne 2015). These issues do not diminish the need for sustainable infrastructure but support careful consideration of equity before and during development. 


\section{Current bike infrastructure development in} Wisconsin

Wisconsin, the first state to implement "rail trails" (bike trails built on existing railroad corridors), continually invests in progressive bike infrastructure that benefits communities. The economic impact of biking in Wisconsin is significant, contributing over $\$ 1.4$ billion to the State annually (Schlabowske n.d.). Near La Crosse, forty miles of new trail are expected to bring over $\$ 300$ million in economic benefits through health, safety, transportation, and air quality (Schlabowske n.d.). In Milwaukee, re-designed streets in East Wauwatosa are making the community more bike friendly and livable, though the economic development has increased property values and displacement (Schlabowske n.d.).

The City of Madison is committed to increasing bike accessibility. For example, the Madison Community Foundation gave a $\$ 99,200$ community impact grant to provide used bikes, helmets, and repairs to underserved kids (Madison Community Foundation n.d.). The Madison Parks Department and International Mountain Biking Association partnered to create more off-road biking areas for overlooked communities (Hubbuch 2020). However, despite designation as a platinum-level bike friendly city by the League of American Bicyclists, the extensive commuter trail system in Madison is not yet uniformly distributed (Scott 2015).

Wedged between two lakes, the city's geography historically fostered bikeability with a less carfocused inner urban layout. In the 1950s, development of wide, high-speed roads caused outward suburban sprawl and less bike friendly development. After 2000, development became bike friendly again at the edges of the city (Hardee 2020). Many of the city's affordable housing options, and consequently, Madison's more vulnerable communities, were developed from 1950-2000 in areas between the urban core and suburban fringe. The city has begun to address this bike infrastructure inequity with projects in vulnerable neighborhoods.

\section{Madison bike projects at risk of green gentrification}

Madison's 2019 Equitable Development Report identifies vulnerable neighborhood tracts based on race, income, education, and rental rate. Ongoing projects in vulnerable areas address inequity in bike infrastructure yet present an opportunity for unintended green gentrification without concrete policy solutions. In western Madison, a $\$ 8.4$ million bike path project in a demographically changing neighborhood created safer passage from affordable residential to downtown areas, allowing for more equitable access to community resources (Elbow 2016). Similarly, near the city's primary community college in eastern Madison, a second project is underway in a tract that has observed demographic change and increased rent/property values. A final re-development project in a gentrifying area (e.g. increases in college-educated populations, higher median incomes, and decreases in persons of color and rental units) with economically vulnerable populations seeks to increase bike infrastructure.

Displacement of residents may occur in areas surrounding the aforementioned bike projects unless preventative measures are taken. Madison's on-going low vacancy rate $(3.7 \%$, approximately half the national average) and affordable housing crisis amplify this issue (Garton 2020; "Multifamily Rental Vacancy Rates" 2021). While the City of Madison has outlined steps it will take to reduce general displacement, there has been no public-facing acknowledgement on the potential equity impact of these new trails. Policy options should be considered in each of these bike project areas to maintain affordability and prevent further displacement.

\section{Policy options}

i. Option 1: Use tax-increment financing (TIF) to create a new tax district to fund new bike paths and affordable housing in the immediate surrounding area When a redevelopment project takes place, the value of real estate in the surrounding area is expected to increase and generate property tax revenue. TIF is a common method to fund redevelopment projects by diverting the future increase of property tax revenue to pay for the project itself. TIF revenue can also fund affordable housing. Greenville, South Carolina implemented this strategy to fund affordable housing immediately surrounding Unity Park, serving as a buffer against displacement while redeveloping the area (Rigolon and Christensen 2019). Madison's current TIF policy requires that $10 \%$ of the district's tax increments be used for affordable housing (Madison Equitable Development Report). A TIF tax 
district typically remains open until all debt and project costs are paid off; of twelve sampled tax districts in Madison, the average district recovered all costs in ten to twelve years (Gromacki 2008). However, Madison also leverages TIF extensions that allow TIF districts to be open an extra year under Wisconsin Statute $\S 66.1105(6)(\mathrm{g})$, provided most of the funding supports affordable housing. \$4 million in 2018 and \$2.7 million in 2020 was generated for affordable housing in Madison by leveraging TIF extensions for three tax districts (Pasque 2017). The revenue from TIF extensions can be used anywhere in Madison. We propose creating a TIF district around new bike infrastructure projects, when possible, to fund the project and affordable housing within the district using TIF and TIF extension revenue.

\section{Advantages}

- Funding affordable housing in the areas surrounding bike trails buffer against displacement.

- Madison's existing policies ensure TIF revenue is spent on affordable housing, with a history of using TIF for infrastructure projects.

\section{Disadvantages}

- Ability to generate money for affordable housing is subject to market fluctuations (Rigolon and Christensen 2019).

- TIF can only be used on new projects since a baseline level of property tax revenue needs to be established in the beginning.

- Madison policy states that TIF can only be used if the TIF revenue is necessary for the project to move forward. An application is submitted by the developers to the City and the Common Council makes the final decision.

ii. Option 2: Leverage developer exactions to fund affordable housing projects in areas around bike infrastructure projects

Developer exactions are provisions where the developer is expected to provide something to a local government in exchange for approvals to proceed with a project, often offsetting the burden of new development on a community. Exactions can include construction of public infrastructure, e.g., roads and affordable housing funding (World Bank Group n.d.). Exactions are applied on a project-by-project basis or through an ordinance. Similarly, impact fees are one- time charges levied by a local government on the developer to cover infrastructure costs associated with the project. Linkage fees, a type of impact fee, are fees per square foot of construction and funds can pay for affordable housing (Inclusionary Housing n.d.). Alternatively, developers can construct affordable housing as an exaction (Madison Equitable Development Report). Not currently utilized, the City of Madison could leverage developer exactions or impact fees for affordable housing funding or construction in the surrounding area in exchange for project approval (Madison Equitable Development Report).

\section{Advantages}

- Developer exactions can be levied on a project-by-project basis to meet the needs of the community.

\section{Disadvantages}

- Impact fees, linkage fees and exactions to fund affordable housing projects require the government to carefully estimate costs (The World Bank n.d.).

- Fees may dissuade developers, potentially harmful in a city with limited housing stock of all types.

- Outside of the most profitable real estate markets, the fees may not provide enough funds to cover the full cost of infrastructure or affordable housing projects (The World Bank n.d.).

iii. Option 3: Use the Madison Area Community Land Trust to acquire land in targeted areas around developing bike path projects

A community land trust (CLT) is a local non-profit that acquires land and uses it for projects that benefit the community, such as creating affordable housing. CLTs build affordable housing on the land and sell it to a qualified homeowner, while retaining ownership of the underlying land. The land is leased to a homeowner typically for a period of ninety-eight years (Semuels 2015). Separating land ownership from home ownership helps keep housing affordable. Madison has one CLT, the Madison Area Community Land Trust (MACLT). Buying a home through MACLT saves homebuyers $30 \%$ on average (MACLT n.d.). The 2021 city budget expanded funding from Madison's Affordable Housing Fund to non-profits like MACLT (Becker 2021). We propose Madison give funds to 
MACLT to acquire land in targeted areas of bike path development, removing adjacent land from the market and developing affordable housing.

\section{Advantages}

- CLTs keep housing prices low for future homeowners by sharing the increase in the home's value with the next buyer, extending affordable housing availability (MACLT n.d.).

- Land stays in community possession and cannot be sold to developers (Semuels 2015).

- People can still buy a home and earn equity on the structure.

\section{Disadvantages}

- Ground fees for land lease (\$75 for single family homes through MACLT) generally do not cover all expenses and CLTs are typically reliant on external funding to sell homes at below market levels (Local Housing Solutions n.d.).

\section{Policy recommendation}

We recommend that the City of Madison enact a policy to prevent green gentrification surrounding any new bike infrastructure project by using a combination of tax increment financing and

\section{References}

Becker, A. 2021. "Madison committee recommends nonprofits, cooperatives for affordable housing funds." The Cap Times, February 9, 2021. https://madison.com/ct/news/local/govt-andpolitics/madison-committee-recommendsnonprofits-cooperatives-for-affordable-housingfunds/article 3fe37fca-b2c3-59a2-a7ec8f1b0ecb2390.html.

Black, C. 2020. “'Green Gentrification' and lessons of the 606." Chicago Reporter, January 30, 2020. https://www.chicagoreporter.com/greengentrification-and-lessons-of-the-606/.

Bloom, M., et al. 2021. "Anti-Gentrification Ordinance Approved, Slapping Developers With Steep Fines For Tearing Down Buildings Near The 606, In Pilsen." Block Club Chicago, March 24, 2021. https://blockclubchicago.org/2021/03/24/antigentrification-ordinance-approved-slappingdevelopers-with-steep-fines-for-tearing-downbuildings-near-the-606-in-pilsen/. community land trusts (Options 1 and 3 ). TIF can only be leveraged for new bike infrastructure projects, but MACLT can be used for ongoing or completed projects. TIF can also only be implemented if all other possible financial alternatives are exhausted, e.g., federal and state funds, bonds, tax credits and loans. If TIF is implemented, we recommend the TIF revenue be used to fund affordable housing projects surrounding the developed area to prevent green gentrification. The MACLT should be leveraged to buy property adjacent to the new development in cases where TIF is not an option. Although these policies may reduce the ability to put redevelopment profits to other uses, proactive investment in affordable housing will ensure that Madison's most vulnerable residents can remain in their current communities. If left unchecked, inequitable access to bike infrastructure could worsen despite the City's efforts to prevent it. Implementing policy to specifically prevent green gentrification in Madison by bolstering affordable housing aligns with the City's goals for equitable development and will ensure that the benefits of future investments are equitable among the community. Furthermore, implementing these policies for public infrastructure projects during development can serve as a model for other cities to consider and proactively prevent green gentrification.

Byrne, J. 2015. "Mayor Emanuel's 606 affordable-housing plan draws doubts." Chicago Tribune, August 12, 2015.

https://www.chicagotribune.com/politics/ctemanuel-606-housing-met-20150811-story.html.

Elbow, S. 2016. "Velo city: Madison's award-winning system of bike lanes and paths continue to grow." The Cap Times, July 20, 2016. https://madison.com/ct/news/local/citylife/velo-city-madisons-award-winning-systemof-bike-lanes-and-paths-continues-togrow/article fd91815e-4008-5fab-bdcaa $8 \mathrm{a} 5 \mathrm{fa} 0 \mathrm{c} 25 \mathrm{~d} 0 . \mathrm{html}$.

Eldridge, M., Burrowes, K., and Spauster, P. 2019. "Investing in Equitable Urban Park Systems: Emerging Funding Strategies and Tools." Urban Institute. https://cityparksalliance.org/wpcontent/uploads/2019/07/Equity and Parks Fu nding 7.16.19.pdf. 
"Equitable Development in Madison: An assessment of factors contributing to displacement and gentrification." November 2019. Madison Common Council. Accessed April 21, 2021. https://www.cityofmadison.com/dpced/plannin $\mathrm{g} /$ documents/Equitable\%20Development\%20Re port\%20111919.pdf.

Garton, N. 2020. "Affordable for whom? Madison's housing crisis continues to leave low income renters behind." The Cap Times, November 25, 2020. https://madison.com/ct/news/local/neighborho ods/affordable-for-whom-madisons-housingcrisis-continues-to-leave-low-income-rentersbehind/article 83b88149-6509-5334-876f24a12b6bf415.html.

Gromacki, Joe. 2008. "Madison TIF Milestones, Performance Summary of Closed TIDs Since 2005." January 7th, 2008. http://legistar.cityofmadison.com/attachments/f 529d2e6-fa2f-4874-9e85-134309eede80.pdf.

Hardee, H. 2020. "Madison gears up for bike path improvements to increase connectivity, safety citywide." Wisconsin State Journal, February 17, 2020.

https://madison.com/wsj/news/local/madisongears-up-for-bike-path-improvements-toincrease-connectivity-safetycitywide/article 80be27b5-b6d3-5935-ab0379e13e738783.html.

Hubbuch, C. 2020. "Trails close to home: Parks initiative offers access to urban adventure for all." The Cap Times, October 5, 2020.

https://madison.com/wsj/news/local/environm ent/trails-close-to-home-parks-initiative-offersaccess-to-urban-adventure-forall/article d92808c6-b149-5969-a4fe700f8ab23164.html.

Inclusionary Housing. n.d. "Linkage Fee Programs." Accessed April 3, 2021.

https://inclusionaryhousing.org/designing-apolicy/program-structure/linkage-feeprograms/.

Local Housing Solutions. n.d. "Community Land Trusts." Accessed April 15, 2021.

https://www.localhousingsolutions.org/act/hou sing-policy-library/community-land-trustsoverview/community-land-trusts/.
Madison Area Community Land Trust (MACLT). n.d. "Madison Area Community Land Trust." Accessed April 8, 2021.

http://affordablehome.org/.

Madison Community Foundation. n.d. "Mad About Bikes is Bringing the Community Together for Good." Accessed on April 3, 2021.

https://www.madisongives.org/nonprofits/madabout-bikes-community-impact-grant-.

“Multifamily Rental Vacancy Rates". 2021. Madison Gas and Electric.

https://www.mge.com/customer-service/formultifamily/multifamily-rental-vacancy-rates.

Ori, R. 2020. "Affordable housing is vanishing as gentrification casts a shadow over The 606. City Council just voted to ban demolitions for 6 months." Chicago Tribune, January 15, 2020. https://www.chicagotribune.com/columns/ryan -ori/ct-biz-606-trail-housing-prices-ryan-ori20200115-wvjgab2h2zd63ko33t2xqerkiystory.html.

Pasque, L. 2017. "Madison extends TIF districts to help fund affordable housing." The Capital Times, May 2, 2017.

https://madison.com/ct/news/local/govt-andpolitics/madison-extends-tif-districts-to-helpfund-affordable-housing/article 3ea0a662-bc8d5a66-ac03-6eaf967757e7.html.

Rigolon, A. and Christensen, J. n.d. "Greening without Gentrification: Learning from Parks-Related AntiDisplacement Strategies Nationwide." University of California-Los Angeles. Accessed April 2, 2021. https://www.ioes.ucla.edu/project/prads/.

Samuels, A. 2015. "Affordable Housing, Always." The Atlantic, July 6, 2015. https://www.theatlantic.com/business/archive/ 2015/07/affordable-housing-always/397637/.

Schlabowske, D. n.d. "Economic Impact of Cycling." Wisconsin Bike Fed. Accessed April 3, 2021. https://wisconsinbikefed.org/what-wedo/advocacy/economic-impact-of-cycling/.

The World Bank, n,d. "Developer Exactions and Impact Fees." Accessed April 10, 2021.

https://urbanregeneration.worldbank.org/node/14.

"The 606". The Trust for Public Land. Accessed April 3, 2021.

https://www.the606.org/about/story/.

Williams, S. 2015. "New Platinum, New Gold Bicycle Friendly Communities." November 13, 2015. https://bikeleague.org/content/new-platinumnew-gold-bicycle-friendly-communities.

Sarah Alexander is the 2021-2022 AGU/AAAS Congressional Science and Technology Policy Fellow. She holds an M.S. and Ph.D. in Civil and Environmental Engineering, with a minor in Life Sciences Communication, from the University of Wisconsin-Madison and a B.A. in Geology from Carleton College. Sarah pursues 
interdisciplinary research to develop, communicate and integrate water resources management strategies for improved resilience of communities vulnerable to climate variability. The former policy engagement chair for the Catalysts for Science Policy, Sarah is passionate about increasing scientific literacy and fostering sciencebased policy to address critical societal challenges.

Benjamin Bachman is an NSF graduate research fellow at the University of Wisconsin-Madison where he is currently pursuing a Ph.D. in Chemistry. He studies the production and chemical properties of artificial diamonds. Ben holds a degree in Chemistry with a minor in Math from the University of Oregon. He is especially interested in policy related to clean water and renewable energy.

Brittany Baur is a Postdoctoral Researcher at the Wisconsin Institute for Discovery at the University of Wisconsin-Madison. She holds a Ph.D. in Computational Sciences and a M.S. in Bioinformatics from Marquette University. She studies the role of the three-dimensional structure of the genome in gene regulation and disease. She is currently the Communications Chair for Catalysts for Science Policy and is passionate about effective science communication and leveraging data science to inform policy decisions.

Julie Davis is the John N. Bahcall Public Policy Fellow for the American Astronomical Society in Washington, DC. She completed a Ph.D. in Astronomy and a minor in Science Communication in August 2021 at the University of Wisconsin-Madison and holds a B.A. in Physics and Astronomy from the University of ColoradoBoulder. She studies the formation and evolution of galaxies using ground- and space-based observatories. She is especially interested in space and climate policy.

\section{Acknowledgements}

The authors wish to acknowledge several members of the Catalysts for Science Policy graduate organization at the University of Wisconsin-Madison for reviewing early versions of the memo and providing valuable feedback. We also thank editors at JSPG for providing suggestions that improved the quality of the memo. 